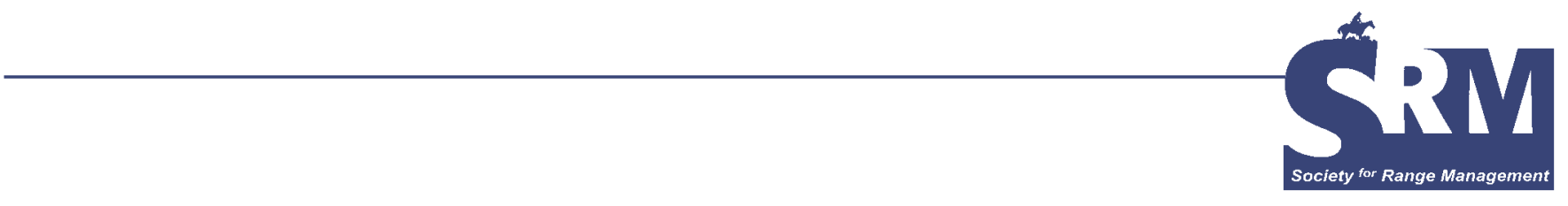

\title{
Fifteenth in a Series: Insight From SRM's Charter Members
}

Editor's Note: This completes the effort to hear from the Society's Charter Members. Thanks to all individuals who participated in the interview process for all your professional help.

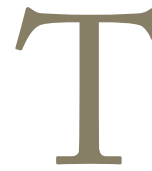

he SRM History Committee has conducted interviews with many of the Society's Charter Members to capture their perspective of events leading to, and subsequent to, the formation of the American Society of Range Management in 1947-48. Interviews from several of these individuals will be shared for today's SRM members to enjoy and learn from.

\section{SRM Charter Member - George Turner}

Editor's Note: George Turner was interviewed by Dr Joe Trlica, Colorado State University Professor Emeritus, on May 5, 2006, in Fort Collins, CO. George resides at 1301 Green St, Fort Collins, CO, and has lived there continuously since 1961.

George now is 91 years of age and was born and raised in Kimberley, Idaho. He received a BS in Forestry from the University of Idaho in 1936 and an MS in Plant Ecology from the New York State College at Syracuse under Frank Egler in 1939. He spent summers of 1936, 1937, and 1938 working for the US Forest Service research branch. Locations included the Manitou Experimental Forest, Frazier Experimental Forest, Black Mountain Experimental Range, and San Joaquin Experimental Range. His research at Syracuse was on land use and plant succession on abandoned fields and woodlots in New York. He had a teaching assistantship, taught half-time and did his Master's research and course work half-time.

George feels he was fortunate in that he spent his entire professional career in the research branch of the Forest Service and all in Colorado. Much of his early work was on influences of various forest and range watershed attributes such as infiltration, runoff, sedimentation, etc. Following receipt of his MS, George was employed by the Forest Service. He received range and ranger training as a follow-up to the Jr Range Examiner exam, but was assigned to research at the Central Plains Experimental Range east of Fort Collins. At that time the Forest Service administered the research, but in later years that responsibility went to the Agricultural Research Service. George initiated the original stocking rate study of light, moderate, and heavy cattle use with cattle provided by the Crow Valley Grazing Association that continues to the present day. Exclosures were established in each of both replications so comparisons could be made of grazed and ungrazed responses on this primarily shortgrass rangeland. Although one replication was removed in later years, the single set of treatments continues after 65 years with regular vegetation measurements. Vegetation was measured using the square foot density method and clipping done using the double sampling method for cover, forage production, and species composition. George reflected on the difficulty of getting the clipped material into bags with the high winds of the plains constantly blowing. Also, prickly pear cactus, at that time, was a large component of vegetation. Sore knees from inadvertently kneeling on cactus were an occupational hazard. He devised a procedure to measure cactus using wire outlines around pads. Research was reported in Forest Service technical bulletins, often coauthored with David Costello and Gerry Klinger.

George was drafted into the US Army Medical Corps after being married to Rita in 1941. His training was in Needles, California, and Rita accompanied him. However, service locations were in the Pacific where he was in charge of personnel records for hospital staffs of up to 320 people. George and Rita are still together and have a daughter and son and several grandchildren.

Following the war, George returned to the Forest Service and was assigned to Delta, Colorado, on the western slope, 
where he remained until 1954. He was housed with management (National Forest System) personnel. The Delta research office was closed in 1954, and he was moved to Grand Junction. In both locations the research sites were somewhat scattered. Major sites were on Black Mesa, and in conjunction with the Bureau of Land Management at Badger Wash (salt desert shrub). Much of the work entailed watershed effects of grazing use of various intensities. In 1961, George was moved to the Rocky Mountain Station headquarters in Fort Collins, but continued to travel to the western slope for field research. He would be able to stay at on-site housing and return home on a regular basis.

While in Fort Collins, George had technical writing responsibilities as the range management editor for research reports and manuscripts. That work lead to a broadening of responsibilities in addition to field research. He continued in this manner until retirement in 1975.

George recalls that word of mouth was how he heard about the beginnings of the American Society of Range Management. He traveled to the 1948 meeting in Salt Lake City with Dave Costello while he was assigned to Delta. He feels that Forest Service researchers and various academic folks were the strongest initial promoters of the Society. After the Journal of Range Management began, that was a good outlet for research reports. He recalls that he and Dave Costello's first paper in the Journal was on growth of blue grama, data collected at the Central Plains Experimental Range. George gives credit to many of his contemporaries in initiating ASRM such as Dr. Vernon Young, Ray Price, Don Hervey, Chuck Terwilliger, Dave Costello, Bill McGinnies, and Bert Reid, in addition to Joe Pechanec, the foremost pusher, in his recollections.

George did not become an officer in either the Colorado Section or the parent society, but he attended meetings on a regular basis, even after retirement. He still peruses the abstracts of Rangeland Ecology \& Management and Rangelands. $\mathrm{He}$ senses that the significant increases in diversity within the profession since he retired over 30 years ago have been generally good. He is concerned that the membership of SRM has not grown when we have such laudable objectives that should universally be appreciated and observed. He feels that young people will benefit in the range profession and rangelands will be the better for that.

(Joe Trlica reflects that he was happy and privileged to have had the opportunity to meet and get to know George. He and I (Tom Bedell) agree that the range profession has such a rich heritage and that we are proud to be a part of it.)

\section{SRM's Charter Member - Clinton H. Wasser}

Editor's Note: Clinton H. "Clint" Wasser now lives at 1320 East Lemon Ave., Lompoc, CA 94306. This statement is compiled from a comprehensive letter to Bill Hurst from Clint and from information contained in the Parade of Presidents. Clint celebrated his 90th birthday November 11, 2005.

Clint, a native of the Salt River Valley near Phoenix, Arizona, received a BS in botany and range ecology from the
University of Arizona in 1937, an MS from University of Nebraska in 1946, and an MF from Colorado State University in 1948. Clint also was a $\mathrm{PhD}$ candidate at University of Minnesota under W. S. Cooper. Except for a year after his BS as a research assistant with the Southwestern Forest and Range Experiment station, Clint spent his professional career at Colorado State University retiring in 1981. During that time period, he taught and did research from 1938 to 1946, was Department Head 1947 to 1957, served as Dean of the College of Forestry and Natural Resources from 1952 until 1969, and returned to teaching in 1969. Clint says he felt he needed to get "re-tooled" after stepping down as Dean so spent one term each at Texas A \& M, University of Georgia, and University of California, Davis in 1970-71. According to the CSU record in Educational History of Range Management in North America, some 33 students graduated with Master's and $\mathrm{PhD}$ degrees under Clint's tutelage.

After retirement, Clint remained in Fort Collins and helped conduct a survey to compile habitat types for Region 2 US Forest Service; authored a manual on the ecology of species suitable for revegetating disturbed land; and co-authored, with Bert Reid and Art Smith, A History of the Society for Range Management 1948-1985. These 3 men received the Frederic G. Renner Award at the Billings SRM meeting in 1989.

Clint's recollection is that he went to the first annual meeting in Salt Lake City, but he says his 90-year-old memory can't verify much more than that. Sections were considered either at the first annual meeting or shortly thereafter. Clint was on sabbatical leave in 1948 and 1949, but alert Colorado members formed a Colorado Section in anticipation of their need in planning and hosting the January 1949 annual meeting. Someone noted a Wyoming Section formed earlier, but this may have been a student Section. Most of his time and effort went into the Colorado Section serving as program Chairperson, speaker, later Historian, and training plant identification teams. He was Colorado Section President in 1952. Section plant contests were held in those early years. He vividly recalls at a Colorado Section meeting, he and Arthur W. Sampson, the "Father of Range Management," sang a western ballad at the request of Bill McGinnies.

Clint was active at the international level. His roles were as Chairperson of the early Education Committee, and on the Plant Identification Contest Committee. He served on the Board of Directors 1962-1964, and as President in 1965-66 presiding at the summer 1965 meeting in Laramie, and annual meeting in New Orleans in January 1966. Some windows of the convention hotel were blown out from a late hurricane (was this before memories of big blows?). (A personal note of interest from Bill Hurst: "I attended this meeting. It rained almost constantly while we were there and froze during the night. In fact, radiators in automobiles froze up and cars were stranded all over the city. Many water pipes in homes froze and broke open. My wife and I left the Hotel Jung to eat dinner at a nearby restaurant. When we reached the sidewalk it 
was so slick with a thin sheet of ice that we couldn't walk. We went back in the Hotel to report this condition and the Head Bellhop said there couldn't be ice in New Orleans because it never froze in the city. I walked outside with him and made him a believer.") Attendance was down due to the severe winter weather especially in the East. Clint visited the Idaho and Texas Sections at their annual meetings. He sought increased membership, but missed the goal as dues had to be increased from $\$ 8$ to $\$ 10$ for Secretary's compensation to phase in a planned full-time Secretary-Treasurer position.

Clint was in the Society of American Foresters before SRM was started. He thought that SRM might develop somewhat like SAF which had nearly a half century head start: ie, national with a national board, national headquarters in Washington, DC, journal (semi-scientific science publication, possibly a regional one) but these latter came recently in SAF's evolution. He is happy with SRM's publications and believes our organization is sound and in good hands. We could profit by listening to our seasoned veterans, give more awards, and recognize meritorious performances of members, Sections and International Officers. He hopes that we can award the equivalent of one or more scholarships and/or fellowships per Section every year. More effort needs to go into junior summer camps, into contests among Sections, and for scholarships at the University levels.

On the international level Clint would like to see Range Condition and Trend analysis become quantified. We need methods of assessing organic matter in the field along with physical properties of soils in assessing sites. If enclosures are outlawed, eg, for areas in wildernesses or national park status, other methods (invisible remote surveys, photographic) need development. Maybe there should be some award for the best new idea every year included among annual recognitions.

Clint said he read Rangelands articles on charter members George Rogler and Pat McIlvain and tended to agree with each. He was disappointed with early acquisitions of intermediate wheatgrass due to Fusarian root rot.

In recent years, Clint moved to California, but stays active gardening (he was known in Fort Collins for his gardening!), and as a part-time unpaid docent at the local Indian Mission Park.

Tom Bedell is a member and former chairman of the SRM History Committee and a member of the Pacific Nortbwest Section living in Philomath, Oregon, tbedell@peak.org. 